\title{
Mind mapping effect on the students' achievement in civic education for elementary school students
}

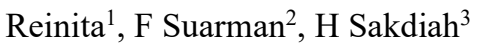 \\ \{reinita_reinita@yahoo.com\} \\ ${ }^{1,2,3}$ Universitas Negeri Padang, Jl. Prof Dr. Hamka Air Tawar, Padang, Indonesia
}

\begin{abstract}
This research is conducted because of some reasons in which teacher-centered learning is still dominant in learning Civic Education and students do not get involved in the learning process. These facts make the student get bored in learning. This research aims to know the effect of Mind Mapping learning model on Civic Education learning outcomes. This type of research is a quantitative research method that used experimental model. The sampling technique uses saturated sampling technique. The sample in this study is about 60 students. The data are analyzed using prerequisite tests such as normality test, homogeneity tests, and hypothesis testing using t-tests. Based on the results obtained, the average score of the pre-test is 68.266 for the experimental class, while the control class gets 67.6. On the other hand, the average score of post-test for the experimental class is 80 and the control class gets 78 . It was found that $t>t$-table $(2.70>$ 1.67) with significant level is about 0.05 .
\end{abstract}

\section{Introduction}

Teachers must be able to prepare themselves to learn well in improving the quality of teaching in schools. It is started by taking an action in the formulation of learning objectives that are aligned to the students' development level, students' characteristics, interest in learning media, availability of learning resources, the ability of the teachers to carry out teaching, and selection of appropriate materials and relevancy of learning models to be applied. The selection of an appropriate learning model during the learning process is something that can support the learning objectives to be achieved.

Learning model is a conceptual framework that describes a systematic procedure in organizing learning experiences to achieve learning objectives [1]. Learning model is used to present a whole set of teaching materials covering all aspects of the media before and after learning is carried out by the teacher and all related facilities that are used directly or indirectly in the learning process [2]. One learning model that can be used to achieve the goals of the learning process is a mind mapping model.

Mind mapping is one way to record learning material that makes it easy for the students to learn and it is categorized as a creative note technique. Mind mapping is a graphics technique that can provide easy ways in thinking and memorizing [3]. The other said that it improves the traditional recording. Further, the advantages of Mind Mapping for students become an interesting study of real problems. It trains the students' thinking so that they could bring good and systematic ideas (Parikh 2016) [4]. In addition, Mind Mapping also teaches the students to create a sense of responsibility in solving problems. The benefit of Mind Mapping is making learning to be interesting because it starts from the real problem [3]. It can 
train the students' thinking that is relevant to the study of problems, can increase collaboration between students because learning is done in groups, maybe for students to put ideas or ideas in a good and systematic way and to determine their competence.

Furthermore, mind mapping can also increase students' interest and stimulate students' news idea to make them participate in the learning process. Thus, these advantages make Mind Mapping is very suitable to be used in civic education. One of the subjects that must be taught by the teachers in primary schools and the subject of civic education. Therefore, a teacher must be able to achieve learning goals well, especially the learning objectives of citizenship education [5]. Civics Education is a subject that is more focused on efforts to provide understanding and shape the students into citizens who have citizens noble values in carrying out their rights and obligations as intelligent, skilled, and marked by Indonesian citizens that have been mandated by the Pancasila and the 1945 Constitution because Civic Education is one of the mandatory learning for students in elementary schools.

Meanwhile, Civics Education is used as a forum to develop and preserve noble values and moral values that are rooted in Indonesian culture. The noble and moral values are expected to be involved in the form of the students' behavior in their daily lives both as individuals and as members of the community, and creatures of Allah SWT, which is an effort to equip the students with basic knowledge and abilities in the relationship between citizens and the state and the introduction of state defense education to become citizens who can be relied on by the nation [6].

Civic Education main goals in Elementary Schools are to form the students to become citizens who understand and are able to carry out their rights and obligations as Indonesian citizens. In addition, Civic Education aims to help the students to build the character of good citizens who have the ability to think critically, rationally and logically. This is in line with a statement from the Ministry of National Education which states the purpose of Civics includes: 1). think critically, rationally and creatively in responding to citizenship issues. 2). participate actively and responsibly. It is an intelligent action in community, nation and state activities and anti-corruption. 3). Develop positive and democratic to shape themselves based on the characteristics of Indonesian people to live together with other nations. 4). Interact with other nations in world regulations directly or indirectly by utilizing information and communication technology [7].

However, the realization of Civic Education main learning objectives is related to the quality of education in which teachers look for in schools. They are required to help the students to think critically and rationally so that they can have more responsible attitudes. On the other hand, it is helping to develop positive attitudes and democratic lives of people in nations. Therefore, researchers also conducted interviews with fifth-grade teachers of V.A and V.B class at 09 Belakang Balok elementary school. It was found from the interviews that the teachers never use the Mind Mapping model in the learning process, especially for Civic Education. Mind Mapping is one of the learning innovations that can help the students to achieve optimal learning outcomes. Its use as an innovation of the problems raised above. This fact is in line with the research conducted by Adi Saputra, entitled "The Effect of Mind Mapping Models with Student Civics Learning Outcomes in Class V Elementary Schools". The results of the study showed that there is a significant influence on student learning outcomes using Mind Mapping compared to conventional student models. It can be seen from the difference in the average value of student learning outcomes in the experimental group higher than the control group $80>78$. These background descriptions identified some problems from the background above. The problems that can be identified are as follows: 1) The teacher dominates more in the material (the teacher is more active in student learning) 2) 
The teacher tends to read the material in the textbook 3) The students are not involved as a whole during the learning process takes place, both student interaction with the teacher and students with students themselves 4) The students do not have the courage to express ideas or opinions in learning. 5) Students attending classes get bored 6) lack of questions and answers in learning 7) teachers never use their Mind Mapping models in learning.

Regarding some of the problems above because of limited time and research to focus more research is needed to limit the problem to be studied, namely "The Effect of Mind Mapping Models on Civics Student Learning Outcomes in Primary Schools". This study aims to determine whether there is an influence on the use of Mind Mapping models on the learning outcomes of Civics students learning at SDN 09 Belakang Balok.

\section{Research Methodology}

This research used quantitative research by collecting data in a quantitative form and processed using statistical techniques [8]. This type of research is experimental recording Experimental research can be interpreted as a research method used to determine the effects of certain treatments on others in controlled conditions [9].

The method used in this study is an experimental study using unequal quasi-experimental designs Group Design Control. Quasi-experimental design is a design study has a control group, but it cannot fully control the external variables that influence the implementation of the trial. Therefore in practice using two sample groups, namely the experimental class and the control class. In this study, the quasi-experimental design for the Control Group Design Nonequivalent was used. The quasi-experimental design used before the pre-test, post-test, and after treatment was described as follows:

Table 1. The tests design of the research

\begin{tabular}{cccc}
\hline Group & Pre-test & Treatment & Post-test \\
\hline Experimental & $\mathrm{O} 1$ & $\mathrm{X}$ & $\mathrm{O} 2$ \\
Control & $\mathrm{O} 3$ & - & $\mathrm{O} 4$ \\
\hline
\end{tabular}

[8]. Description:

X : Mind Mapping Model.

O1 : Pretest (Pre-learning activities using Mind Mapping)

O2 : Post-test (Question forms after using Mind Mapping).

O3 : Pre-test (Pre-learning question trial using conventional method)

O4 : Post-test (Post Learning activities using conventional method).

The population was the entire object or subject targeted as a source of research data. Then the population in this study were all fifth-grade students from SDN 09 Belakang Balok. The students were divided into two groups with a total number of 30 students in V.A and class V.B with a total number was 30 students. The sampling technique used in this study was nonprobability sampling which is a type of saturation. In the end, sampling was a technique of sampling saturated determination if all members of the population were involved as sample [9]. The test used in this study was a written test in the form of multiple-choice questions. There were 30 questions before being tested with four choices of answers a, b, c, d questions. The question test is conducted on a sample of outside students. This trial was conducted to obtain valid and reliable results. In addition, there are also various levels of difficulty and 
power, so that the instrument is decent and good. There were questions have been tested to be conveyed in the pre-test and post-test in the experimental and control class.

\section{Result and Discussion}

\subsection{Result}

In this section, a pretest was conducted in order to measure the students' initial knowledge about Civic Education in Indonesia. The material mastering was described in describing material obtained from the following data.

Table 2. Pre-test data description of experiment and control class

\begin{tabular}{lcc}
\hline \multicolumn{1}{c}{ Description } & \multicolumn{2}{c}{ Pretest } \\
& Experimental class & Control class \\
\hline $\mathrm{N}$ & 30 & 30 \\
Minimum & 48 & 48 \\
Maximum & 96 & 88 \\
Mean & 68266 & 67,6 \\
Average & 77.9 & 77.9 \\
Mode & 71.8 & 71.5 \\
Difference & 204.0644 & 187.9724 \\
Standard & 14.28511 & 13.7103 \\
Deviation & & \\
\hline
\end{tabular}

Table 2 above showed the results of the second-grade pre-test. It could be noted that in the experiment class, the minimum score of the class was 48 . While the maximum score was 96. Then, the average score was 68.266 , the median was $77.9,71.8$ the variants, the mode was 204.0644, and the standard deviation was 14.28511. Whereas, the lowest score in control class was 48 , the highest score was 88 , the average score 76.6 , the median was $77.9,71.8$ for mode, 187.9724 for variant, and the standard deviation was 13.7103. This fact showed that the pretest scores of experiment and control class did not give any significant effect or difference. The classes that were taught using Mind Mapping model was the experimental class that had the same abilities as the class taught using conventional learning that controls the class.

Thus, the data description of Post-test for the Experimental and Control Class made the learning process with different treatment. Then, the results of post-test aimed to measure the students' final results in learning.

Table 3. The post-test results of experiment and control class.

\begin{tabular}{llc}
\hline \multicolumn{1}{c}{ Description } & Trial & $\begin{array}{c}\text { Posttest } \\
\text { Classroom Control Classroom }\end{array}$ \\
\hline $\mathrm{N}$ & 30 & 30 \\
Minimum & 60 & 60 \\
Maximum & 96 & 88 \\
Mean & 80 & 78 \\
Average & 86 & 82.5 \\
Mode & 83 & 80.68 \\
Difference & 80.5517 & 89.1034 \\
Standard Deviation & 9.4394 & 8.9750 \\
\hline
\end{tabular}


Table 3 above showed the post-test result of the two classes. It can be described that the lowest score in the experiment class was 60 , while the highest score there was 96 . The average score was 80 , the median was 86 , the mode was 83 , the variant was 80.55172 , and the standard deviation was 9.43946 . On the other hand, the lowest score in the control class was 60 , while the highest score in this class was 88 . The average score was 78 , the median was 82.5 , the mode was 80.68 , the variant was 89.10344 , and the standard deviation was 8.975061 . This result indicated that the average score of the two classes showed a significant difference since the average score of each was 80 for the experimental class and 78 for the control class. Thus, it can be concluded that the post-test score of experiment class was higher than the control class.

\subsubsection{Normality pre-test}

Normality test in the initial test was done using the Liliefors. The test was significant at $\alpha$ $=0.05$, while the data used were the final results of Civic Education learning on the material of the joint decision form. The normality test was used to determine whether the data were normally distributed or not. When the number of $<\mathrm{L}$ table criteria was measured at a certain level of significance and confidence, the data were said to be normal.

Table 4. Pre-test description of normality test data for experiment and control class

\begin{tabular}{lll}
\hline \multicolumn{1}{c}{ Statistical } & \multicolumn{1}{c}{ Trial } & \multicolumn{1}{c}{ Pretest } \\
& \multicolumn{1}{c}{ Control } \\
\hline Sample (n) & 30 & 30 \\
Lcount & 0.011323 & 0.017116 \\
Ltable & 0.161 & 0.161 \\
Category & Normal & Normal \\
\hline
\end{tabular}

The normality test of the experiment class was $0.011323<0.161$ or less than the L-table and L-count at the significant level $\alpha=0.05, \mathrm{n}=30$. Meanwhile, the normality test of the control class was $0.017116<0.161$ or L-count was smaller than the significant L-table level $\alpha$ $=0.05, \mathrm{n}=30$. The L-count was smaller than L-table. Thus, it can be said that the pre-test data of experimental and control class were in the normal category.

\subsubsection{Homogeneity pre-test}

The homogeneity of the TEST TWO variance treatment group in this study was conducted by calculating the F-Count variant among the largest and smallest variance of the two classes tested. The calculation was done to divide the largest variance from the smallest variants of the tested group and compare it to the F-table at the significant level $\alpha=0.05$. The degrees numerator and the denominator was 2929 from 1.67.

Table 5. The result of pre-test in homogeneity test

\begin{tabular}{|c|c|}
\hline \multirow[t]{2}{*}{ Statistics } & Pretest \\
\hline & The control group \\
\hline Variants & 89.1034 \\
\hline The largest variant & 89.1034 \\
\hline The smallest variant & 80.5517 \\
\hline $\mathrm{F}(\max )$ count & 1.1061 \\
\hline $\mathrm{F}(\max )$ tables & 1.67 \\
\hline Conclusion & Homogeneous \\
\hline
\end{tabular}


It can be seen from the table that F-Count for the results of the pre-test homogeneity test reached 1.1061 , while the $\mathrm{F}$ table with was $(29 ; 29 ; 0.05)=1.67$. When these two were compared, lower F-count and F table were only $1.1061<1.67$. Thus, it can be concluded that the two groups of the students that the experimental class and the control class were at homogeneous pre-test.

\subsubsection{The data of Pre-test simulation}

$\mathrm{T}$-test in the pre-test shows that $\mathrm{t}>\mathrm{t}$ table which was around $0.6936<1.67155$. So, the null hypothesis (Ho) was accepted and the alternative hypothesis (Ha) was rejected. Then, there was no significant difference between the pre-test result of the experimental class VA and VB as the control class. It could be meant that both classes had the ability for both homogeneous classes and are appropriate for use as samples.

\subsubsection{The homogeneity data after the random test}

The calculation is to divide the largest variance by the smallest variance of the tested group and compare it to the $\mathrm{F}$ table at a significant level of $\alpha=0.05$. This numerator degree of freedom 29 and 29 denominators of 1.67. Based on the posttest test results the homogeneity calculation of 1.1061 , whereas F table with $(29 ; 29 ; 0.05)=1.67$. When compared, smaller Fcount $\mathrm{F}$ table or $1.1061<1.67$. This means that Ha was accepted. Therefore, the two groups of students in the class and the experimental control class in a homogeneous posttest

\subsubsection{The test result of hypothesis}

The test was done to determine whether the hypothesis was rejected or accepted. After the post-test data on learning outcomes of good Civic education in the classroom either in control or experiments classes were considered normally distributed and had homogeneous variance, the hypothesis testing was performed. Post-test on data t-test aims to determine whether there is an influence from Mind Mapping used or not.

The prerequisite analysis of test data and homogeneity normality state that the two samples are normal and homogeneous, so the calculation of data analysis can be done using the t-test formula, at a significance level of $5 \%$ and "df / db $=\mathrm{n} 1+\mathrm{n} 2-2$ " with the following criteria: $(t>t$ table $=$ Ha accepted $)$ and $(t<$ table $=$ Ha rejected $)$..

Table 6. The Hypothesis Result

\begin{tabular}{llc}
\hline \multicolumn{1}{c}{ Description } & \multicolumn{1}{c}{ Posttest } \\
\hline Class & Trial & Control \\
$\mathrm{N}$ & 30 & 30 \\
Average & 80 & 78 \\
Talk active & \multicolumn{2}{c}{2.40146} \\
T Table & \multicolumn{2}{c}{1.67155} \\
Conclusion & \multicolumn{2}{c}{ No significant } \\
\hline
\end{tabular}

Th3 post-test result was $=2.40146$ and $\mathrm{t}-$ table $=1.67$ significance 0.05 and degrees of freedom $(\mathrm{df} / \mathrm{db}=30+30-2=58$ ) shows that $\mathrm{t}>\mathrm{t}$ table or $2.40146>1.67$ so that Ho is rejected, it can be said that Ha was received post-test data or the final test shows the effect on Mind Mappin. This Mind Mapping category was used in this study. 


\subsection{Discussion}

The post-test hypothesis and the t-test score found that t-count was higher than the t-table that was $2.40146>1.67$. Further, the null hypothesis (Ho) was rejected and the hypothesis (Ha) was accepted. The calculated score was higher than T-table that showed the influence or significant difference between the two classes. It can be concluded that the use of Mind Mapping in learning affects student learning outcomes. If $\mathrm{Ha}>\mathrm{Ho}$ there is no meaningful effect of the free medication variable (Mind Mapping) (Irianto, 2015: 99). This statement can be seen from the learning outcomes result of experimental class students which they got on average 80 higher than the learning outcomes of the average control class which was only 78 .

The results of the analysis indicated that there was a significant positive effect of the using Mind Mapping on learning outcomes for Civic Education students at SDN 09 Belakang Balok. The students in the learning process used Mind Mapping as a free model and more active than students who study with conventional learning. The model of activities using Mind Mapping learning makes the students learn to work with group members and may be responsible for assignments given to groups.

Then, learning using Mind Mapping model makes the students happy and easy to understand. They also remember the material presented by the teacher. Where students are asked to take responsibility for the Mapping model. This model can also explore the students' potential in completing assignments given by the teacher. Implementation of learning in the classroom in conventional learning is controlled given. Whereas, the students are passive and only listen to the explanation from the teacher. This can be seen when students in the classroom experience control difficulties in learning they do not want to ask or are embarrassed to ask the teacher. They only do what the assigns teacher without comment.

However, the initial stage in the control class is managed to appreciate the teachers' activities, the exploration stage of the students are given reading material together with the experimental class. After they are asked to do readings to master reading material, the next step is the elaboration of students to listening to explanations about the material from the teacher. When the teacher finishes explaining to the students the material is asked to work on questions as an exercise. Then discussed together. While the confirmation stage of the teacher provides opportunities for students to ask questions and provide conclusions and are related to reinforcing the material.

On the other hand, the students are active and directly involved in the learning process, while the teacher is only a facilitator. At the apperception stage, teachers explore the students' knowledge about the material to be taught they actively seek information about the material to be taught by answering and asking questions about the material. In the exploration phase, the teacher opens a student scheme about the material that will be taught to sing songs from Sabang to Merauke.

In the elaboration stage, some students who have concept or problem will be addressed and the problem must be those who have alternative answers to the material to be taught. Then, students are given worksheets and work on the incomplete Mind Mapping worksheets. At the confirmation stage, the teacher asks students to display their work in front of the class and read the results of the discussion. In the final stage is the teacher together with students conclude today's lesson.

The experimental class students had more freedom in learning activities and felt happy and easy to remember the material presented, compared to the control class that looked more passive and boring. In fact, it can be seen from the learning outcomes that are very different between the experimental class and the control class. Based on the post-test data analysis, the 
results of the two classes are usually distributed. Homogeneity after treatment shows that all data have homogeneous variants. From the previous discussion, it can be seen that the average results of the cognitive learning experiments (post-test) of the VB grade students in Negeri 09, Belakang Balok that used Mind Mapping model was 80 and the control class VA is conventional for learning is equal to 78. Based on the post-test hypothesis test performed using the $\mathrm{t}$-test obtained since $\mathrm{t}>\mathrm{t}$ table $(2.40146>1.67)$, then $\mathrm{H} 0$ is rejected, Ha is accepted. The results showed that the effect of using Mind Mapping on the learning outcomes for Civic Education subject in class V 09.

\section{Conclusion}

It can be said that the result of Mind Mapping in Civic Education is based on the results of data analysis. It can be concluded that there is an influence on the use of Mind Mapping in the results of class Civics at SDN 09 Belakang Balok learning. The differences in Civic education (PKN) learning, while outcomes for experimental class students.

Mind Mapping model can use in control using and conventional learning. This is shown from the results of the calculation of the hypothesis post-test test through t-test at the level of 0.05 , where $t>t$ table is $2.40146>1.67$. In addition, the average learning outcomes of civic education students (PKN) in Experiments class is higher than the control class in the material describing the Republic of Indonesia with an average score of civic learning outcomes 80 for the experimental group and an average score of PK78 learning results for the control group. These facts show that the learning outcomes of civic education in the experimental group are better than the learning outcomes in the control group. Thus, it can be concluded that Mind Mapping can affect the learning outcomes of civic education students.

\section{Acknowledgments}

Thank you to Universitas Negeri Padang for permitting the research.

\section{References}

[1] Trianto 2011 Pembelajaran Terpadu (Jakarta: Bumi Aksara)

[2] Istarani 2012 Model pembelajaran Inovatif (Medan: Media Persada)

[3] Istarani 2014 Model pembelajaran Inovatif (Medan: Media Persada)

[4] Parikh and Nikhilkumar D 2016 The International Journal of Psychologi India 3148

[5] Reinita 2017 Advances in Social Science, Education and Humanities Research 118570

[6] S Ahmad 2013 Teori dan Pembelajaran di Sekolah Dasar (Jakarta: Kencana)

[7] Kemendikbud 2006 Kurikulum Tingkat Satuan Pendidikan (Jakarta:BSNP)

[8] Sugiyono 2009 Metodologi Penelitian Kuantitatif Dan Kualitatif (Bandung: Alfabeta)

[9] A M Yusuf 2014 Metode Penelitian Kuantitatif Kualitatif Dan Penelitian Gabungan (Jakarta:Prenadamedia Grup) 